Research Article

\title{
Misconceptions of biology education students in Biochemistry Course during the COVID-19 pandemic
}

Poncojari Wahyono a,1, ${ }^{*}$, Eko Susetyarini a,2

a Department of Biology, Faculty of Teacher Training and Education, Universitas Muhammadiyah Malang, Jl. Raya Tlogomas No. 246,

Malang, East Java 65144, Indonesia

1 poncojari@umm.ac.id*; ${ }^{*}$ susetyorini@umm.ac.id

${ }^{*}$ Corresponding author

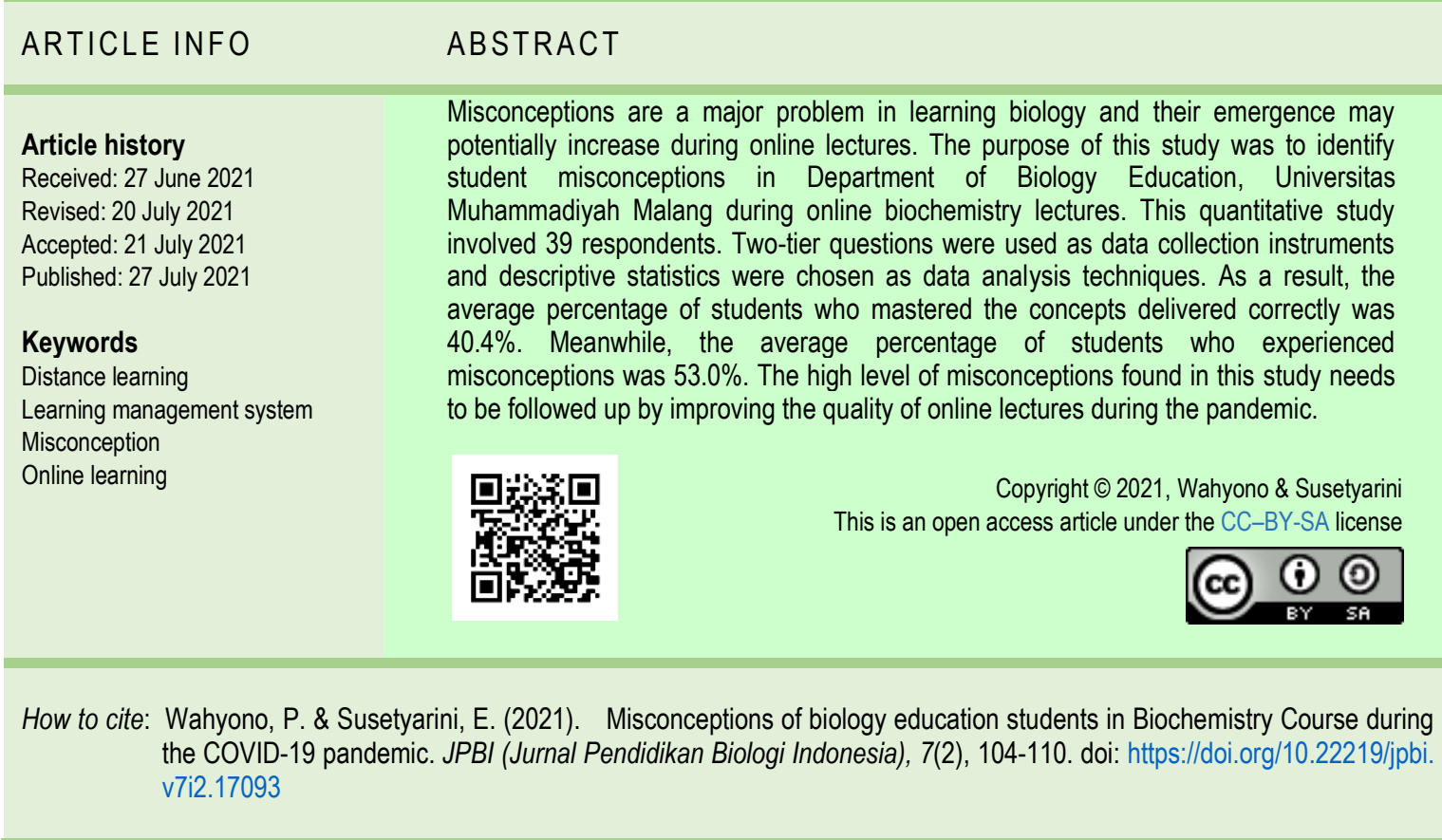

\section{INTRODUCTION}

Biochemistry is a branch of biology that contain many difficult concepts (Fauzi \& Fariantika, 2018; Halmo et al., 2018). Biochemistry studies biological processes at the cellular and molecular levels (Mohammad, 2017). As a basic science, biochemistry has many sub-branches such as bioorganic chemistry, clinical biochemistry, and immunochemistry. So, biochemistry has become the basis for understanding all disciplines related to biology, such as biotechnology, environmental engineering, pharmacy, to medicine (Usman, 2018). Therefore, biochemical literacy is important for students in the fields of science, including biology.

As the breadth and depth of biochemistry increases, a lot of new information is learned in biochemistry. Biochemistry textbooks are becoming thicker and more biochemical concepts and practices have to be learned. Students also often have to memorize facts and figures when studying biochemistry. Therefore, the issue of how to make biochemical knowledge and principles more interesting to study, easier to understand, and more useful has become a major concern for teachers. The reason is, this condition causes the 
emergence of negative traits of students towards biochemistry, such as feeling bored, finding it difficult to study, or feeling unimportant to study biochemistry.

Due to the breadth and amount of information that must be learned in biochemistry, the increase of misconceptions among students is inevitable. Misconceptions often go undetected and persist during learning (Queloz et al., 2017). Misconceptions can be caused by learning errors at previous academic levels. Misconceptions may also be generated through the use of analogies that oversimplify the scientific concept being studied. In addition, misconceptions can also be caused by misinformation that has been read by students from several sources that are less credible (Duda et al., 2020).

Apart from the importance of biochemical literacy as well as low attitudes and high misconceptions about biochemistry, the education field faces other problems that cannot be underestimated. The problem is a drastic change in learning conditions, from face-to-face learning to online learning (Rajhans et al., 2020). This condition is caused by the COVID-19 outbreak that has attacked the world since the end of 2019 (Singhal, 2020).

Various studies examining biology learning during the COVID-19 pandemic were carried out. There is research trying to identify teacher readiness to implement online learning (Barbour et al., 2013; Yusuf, 2020). Several other studies have attempted to examine the impact of online learning on the level of student satisfaction (Mok et al., 2021) or competence (Martha et al., 2021). Research in biochemistry lectures has also been carried out, but the research problem is more focused on student learning difficulties in online biochemistry practicum (Qonita et al., 2021). On the other hand, several studies have also examined misconceptions in Biology learning. The research not only focuses on mapping and diagnosing misconceptions in students (Dikmenli, 2010; Raharjo et al., 2019; Susanti, 2018), but there are also studies that develop and evaluate diagnostic instruments that can accurately identify misconceptions in students (Queloz et al., 2017; Suwono et al., 2021). However, there is no research that specifically wants to analyze the existence of misconceptions in biochemistry lectures in Indonesia, especially during pandemic era. Based on the background that has been described, it is necessary to explore students' misconceptions in biochemistry lectures during the pandemic. This kind of research will be an important evaluation and policy basis for optimizing the lecture process during the pandemic. Therefore, in this study, the accuracy of student concepts during online learning of Biochemistry lectures at the Universitas Muhammadiyah Malang (UMM) was carried out.

\section{METHOD}

This research was a quantitative study that carried out at UMM, Indonesia. The study was conducted from August to December 2020. This study involved 39 students from the Department of Biology Education who were taking Biochemistry lectures during the COVID-19 pandemic. The Biochemistry course utilizes the learning management system (LMS) provided by UMM. The LMS used uses the Canvas platform. The platform is packaged into a special address, namely https://elmu.umm.ac.id/.

The data collected in this study was quantitative data obtained from the test instrument. The test instrument was in the form of a two-tier instrument which initially consisted of 20 question items. After being tested for validity using Pearson Correlation, item numbers $1,4,15$, and 20 were eliminated because they were invalid. The remaining sixteen items were then analyzed to determine the reliability of the instrument used. The results of the reliability test using Cronbach alpha inform that the instrument is reliable.

Data collection was carried out after the Biochemistry lecture was carried out for ten meetings. The ten meetings were started by unit 1 , namely the unit "Preliminary Understanding of Biochemistry and Macromolecules" and ended by unit 4, namely the unit "Metabolism". One unit consists of several learning activities. In each learning activity, students are directed to have a discussion after they have listened to the video that has been embedded into the science page.

After data collection was carried out, students' answers were grouped into four categories, namely 1) correct and sure; 2) correct and not sure; 3) not precise and sure; and 4) imprecise and unsure. Students are said to have the right understanding if their responses fall into the first category, while they are said to have misconceptions if their responses fall into the third category. If the responses belong to the second category, then the accuracy of their answers is considered to come from luck or other factors. If the response fall into fourth category, the students do not have a conceptual understanding of the concept being asked. The data obtained were analyzed by calculating the percentage to see the distribution of the responses to each item asked. 


\section{RESULTS AND DISCUSSION}

Misconceptions have become a serious problem and challenge in learning biology. The misconception data in this study is based on student responses when answering questions from a two-tier instrument. The percentage of student answers is presented in Figure 1.

Based on Figure 1, the average percentage of students who have a proper understanding of the concept of biochemistry was $40.4 \%$. This response category indicates that respondents have a conceptual understanding of the concept being asked and they believe that the concept they have is correct. The average percentage that does not reach $50 \%$ of all students indicates that the mastery of biochemistry concepts of students who take biochemistry courses online is still not optimal. On the other hand, the average percentage of students who are unsure of the answer even though the answer choice is correct was only $2.4 \%$. This answer category indicates that the accuracy of the answer could be due to luck when choosing the answer. In addition, their disbelief indicates their doubts about the concepts they have learned.

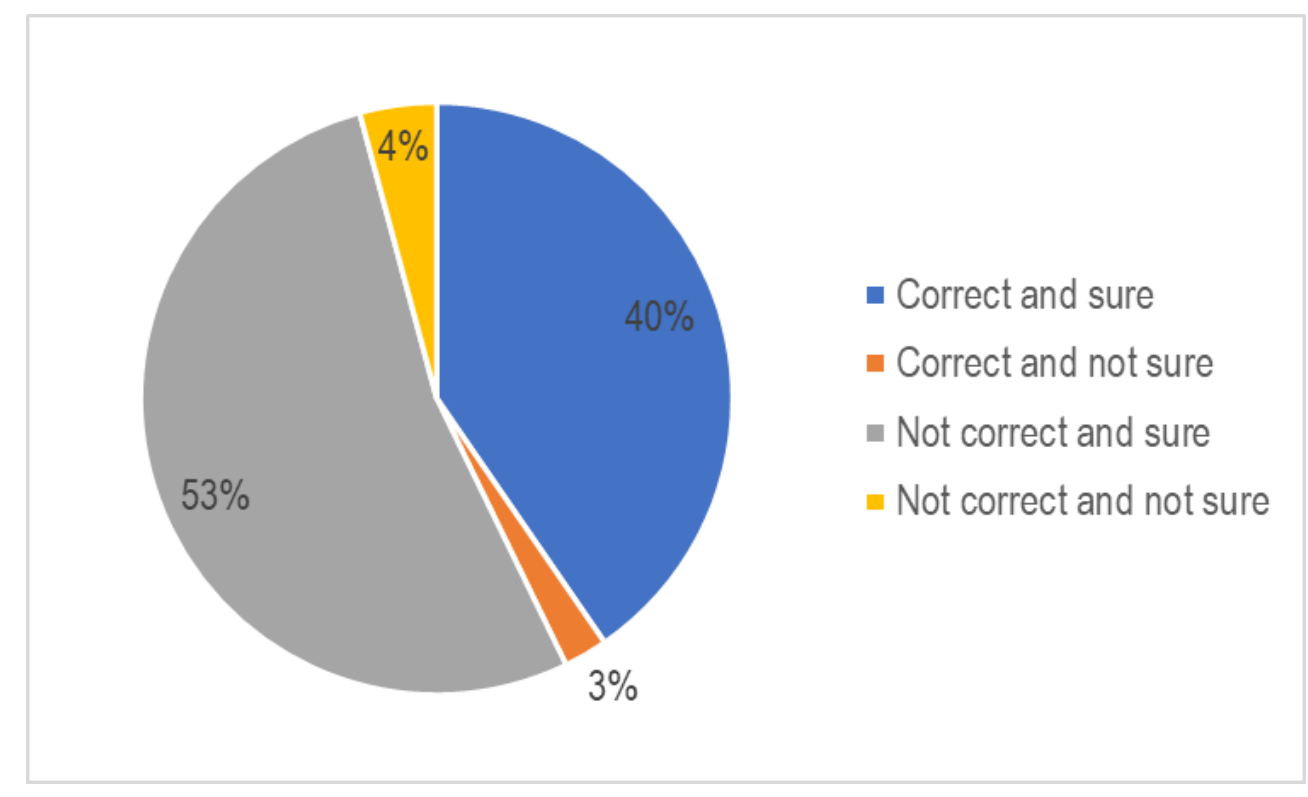

Figure 1. Percentage of students' answers on the misconception diagnostic test

Table 1. Distribution of student answers in each item

\begin{tabular}{ccccc}
\hline Items & Correct and sure & Correct and not sure & Not correct and sure & Not correct and not sure \\
\hline 1 & 51.3 & 7.7 & 38.5 & 2.6 \\
2 & 10.3 & 0.0 & 89.7 & 0.0 \\
3 & 17.9 & 0.0 & 76.9 & 5.1 \\
4 & 30.8 & 7.7 & 59.0 & 2.6 \\
5 & 71.8 & 5.1 & 23.1 & 0.0 \\
6 & 12.8 & 0.0 & 82.1 & 5.1 \\
7 & 71.8 & 5.1 & 23.1 & 0.0 \\
8 & 17.9 & 0.0 & 76.9 & 5.1 \\
9 & 59.0 & 0.0 & 35.9 & 5.1 \\
10 & 51.3 & 5.1 & 33.3 & 10.3 \\
11 & 64.1 & 2.6 & 33.3 & 0.0 \\
12 & 74.4 & 2.6 & 23.1 & 0.0 \\
13 & 20.5 & 0.0 & 76.9 & 2.6 \\
14 & 28.2 & 2.6 & 61.5 & 7.7 \\
15 & 59.0 & 0.0 & 33.3 & 7.7 \\
16 & 5.1 & 0.0 & 82.1 & 12.8 \\
\hline
\end{tabular}


The average percentage of students who are sure of their answers even though their answers are wrong was $53.0 \%$ (Figure 1). The response category of this answer represents the level of students' misconceptions. In these conditions, they feel confident that their understanding of the concept is correct. In fact, the understanding they have is not the right understanding. The average percentage indicates a very high level of misconception because the average percentage has exceeded $50 \%$. On the other hand, the average percentage of students whose answers were incorrect and unsure of the answers they chose was only $4.2 \%$. These answers represent a condition where students feel they do not have a conceptual understanding of the concept being asked.

Furthermore, the distribution of student answers in each item is presented in Table 1. Based on Table 1, almost all items have a high percentage of not correct and sure answers. The percentages ranged from $23.1 \%$ (item number 5,7 , and 12 ) to $89.7 \%$ (item number 2). Items number 5, 7, and 12 respectively ask about protein structure, protein denaturation, and the role of lipids in life. On the other hand, item number 2 asks about the role of water as an important component in life. The high category of "not correct and sure" answers in almost all items shows that almost all the biochemical concepts have a high level of misconception.

The level of accuracy and concept error is related to the level of difficulty of a concept being studied and understood (Erman, 2017). This condition may increase when the interaction between students and lecturers becomes less than optimal. There are some concepts, especially abstract concepts that must be conveyed with care because they are often a source of misconceptions (Üce \& Ceyhan, 2019). Abstract concepts will be difficult to learn by students whose cognitive level is still less developed (Halim et al., 2014). In addition, when interaction cannot occur directly, there are often several environmental and learning distractions that can increase the frequency of misconceptions. Incomplete information is also the cause of the emergence of misconceptions.(Erman, 2017). Incomplete information also has the potential to increase when students cannot attend directly in class.

In the pandemic era, face-to-face learning opportunities are very limited. In the pandemic era, face-to-face learning opportunities are very limited. The reason is that the presence of COVID-19, which is highly contagious (Wu et al., 2020) has caused policy makers to implement physical distancing in almost all sectors of life (Chu et al., 2020), including the education sector (Azhari \& Fajri, 2021; Gunawan et al., 2020). This policy led to the transformation of face-to-face learning into online learning (Al-Kumaim et al., 2021; Atmojo \& Nugroho, 2020). Through this kind of learning, the potential for decreasing the quality of learning and the emergence of misconceptions during lectures is increasing.

Misconception is a major problem in the biology education field. The difficulty of students mastering the biology concept is rooted in at least 3 things. First, misunderstandings and barriers to the acquisition of scientific concepts during instruction and persist even after instruction (Dikmenli, 2010; Elisa et al., 2007). Second, the scope and complexity of biology and the nature of microscopic structures that are invisible to the human eye often result in students having difficulty conceptualizing concepts (Sesli \& Kara, 2012). Third, the complex and growing area of biological science becomes a challenge for teachers in teaching (Mermelstein \& Costa, 2017) so that teachers can become propagator of misconceptions in students (Yates \& Marek, 2014).

Regarding the findings, the online lecture design needs to be optimized so that misconceptions can be minimized. Lecture design needs to adopt several learning models that have previously been reported to be able to reduce the level of misconceptions, such as dual situated learning (Kurniawan et al., 2020) and discovery-inquiry learning (Tompo et al., 2016). However, because some of these learnings are still based on face-to-face meetings, the development of innovative online-based learning designs needs to be formulated in further studies. On the other hand, related to practical activities, case-based learning is recommended to be implemented in the current pandemic era (Thibaut \& Schroeder, 2020).

Apart from the findings that have been obtained, this study also has limitations. The first limitation is related to the number of samples that are still not too large. This study only involved 39 students. When referring to the population defined in this study, the number of samples is already representative. However, further research involving a larger population scale and sample size also needs to be done. This kind of research will provide a broader picture of the phenomenon of misconceptions in biology learning, especially on biochemical concepts. In addition, the limitations of this study also come from the diagnostic instruments used. Although two-tier instruments are commonly used in diagnosing students' misconceptions, the use of other instruments such as tree-tier or four-tier is also recommended to be applied in further research. In addition, the 
development and validation of instruments also need to be refined in further research. With a better development and validation process, the research findings will also be more accurate.

\section{CONCLUSION}

After attending online Biochemistry lectures, the average student who experienced misconceptions was $53.0 \%$, while students who mastered the right concept were only $40.4 \%$. A quasi-experimental research to examine the effect of applying some innovative online-based learning needs to be carried out in further research. The focus of research in future research can also touch other aspects of thinking skills and 21st Century competencies. The habit of online lectures and optimizing the use of LMS needs to be continued because it is in line with the form of 21 st Century-based lectures in the current digital era.

\section{REFERENCES}

Al-Kumaim, N. H., Alhazmi, A. K., Mohammed, F., Gazem, N. A., Shabbir, M. S., \& Fazea, Y. (2021). Exploring the impact of the COVID-19 pandemic on university students' learning life: An integrated conceptual motivational model for sustainable and healthy online learning. Sustainability, 13(5), 2546. https://doi.org/10.3390/su13052546

Atmojo, A. E. P., \& Nugroho, A. (2020). EFL classes must go online! Teaching activities and challenges during COVID-19 pandemic in Indonesia. Register Journal, 13(1), 49-76. https://doi.org/10.18326/ rgt.v13i1.49-76

Azhari, B., \& Fajri, I. (2021). Distance learning during the COVID-19 pandemic: School closure in Indonesia. International Journal of Mathematical Education in Science and Technology, 1-21. https://doi.org/10. 1080/0020739X.2021.1875072

Barbour, M. K., Siko, J., Gross, E., \& Waddell, K. (2013). Virtually unprepared: Examining the preparation of K-12 online teachers. In Teacher Education Programs and Online Learning Tools: Innovations in Teacher Preparation (pp. 60-81). https://doi.org/10.4018/978-1-4666-1906-7.ch004

Chu, D. K., Akl, E. A., Duda, S., Solo, K., Yaacoub, S., Schünemann, H. J., Chu, D. K., Akl, E. A., El-harakeh, A., Bognanni, A., Lotfi, T., Loeb, M., Hajizadeh, A., Bak, A., Izcovich, A., Cuello-Garcia, C. A., Chen, C., Harris, D. J., Borowiack, E., ... Schünemann, H. J. (2020). Physical distancing, face masks, and eye protection to prevent person-to-person transmission of SARS-CoV-2 and COVID-19: a systematic review and meta-analysis. The Lancet, 395(10242), 1973-1987. https://doi.org/10.1016/S0140$6736(20) 31142-9$

Dikmenli, M. (2010). Misconceptions of cell division held by student teachers in biology: A drawing analysis. Scientific Research and Essay, 5(2), 235-247. https://academicjournals.org/article/article1380 539915_Dikmenli.pdf

Duda, H. J., Wahyuni, F. R. E., \& Setyawan, A. E. (2020). Plant biotechnology: Studying the misconception of biology education students. AIP Conference Proceedings, 020101. https://doi.org/10.1063/5.0030449

Elisa, A., Sotos, C., Vanhoof, S., Noortgate, W. V. D., \& Onghena, P. (2007). Students ' misconceptions of statistical inference : A review of the empirical evidence from research on statistics education. 2, 98113. https://doi.org/10.1016/j.edurev.2007.04.001

Erman, E. (2017). Factors contributing to students' misconceptions in learning covalent bonds. Journal of Research in Science Teaching, 54(4), 520-537. https://doi.org/10.1002/tea.21375

Fauzi, A., \& Fariantika, A. (2018). Courses perceived difficult by undergraduate students majoring in biology. Biosfer: Jurnal Pendidikan Biologi, 11(2), 78-89. https://doi.org/10.21009/biosferjpb.v11n2.78-89

Gunawan, G., Suranti, N. M. Y., \& Fathoroni, F. (2020). Variations of models and learning platforms for prospective teachers during the COVID-19 pandemic period. Indonesian Journal of Teacher Education, 1(2), 61-70. https://journal.publication-center.com/index.php/ijte/article/view/95/48

Halim, L., Yong, T. K., \& Meerah, T. S. M. (2014). Overcoming students' misconceptions on forces in equilibrium: An action research study. Creative Education, 05(11), 1032-1042. https://doi.org/10.4236/ ce.2014.511117

Halmo, S. M., Sensibaugh, C. A., Bhatia, K. S., Howell, A., Ferryanto, E. P., Choe, B., Kehoe, K., Watson, M., \& Lemons, P. P. (2018). Student difficulties during structure-function problem solving. Biochemistry and Molecular Biology Education, 46(5), 453-463. https://doi.org/10.1002/bmb.21166 
Kurniawan, M. A., Rahayu, S., Fajaroh, F., \& Almuntasheri, S. (2020). Effectiveness of dual situated learning model in improving high school students' conceptions of chemistry equilibrium and preventing their misconceptions. Journal of Science Learning, 3(2), 99-105. https://doi.org/10.17509/jsl.v3i2.22277

Martha, A. S. D., Junus, K., Santoso, H. B., \& Suhartanto, H. (2021). Assessing undergraduate students' elearning competencies: A case study of higher education context in Indonesia. Education Sciences, 11(4), 189. https://doi.org/10.3390/educsci11040189

Mermelstein, C., \& Costa, M. L. (2017). Analysis of undergraduate cell biology contents in Brazilian public universities. 41, 361-368. https://doi.org/10.1002/cbin.10720

Mohammad, O. (2017). Recent trends in biochemistry and biotechnology. J Biochem Biotech, 1(1), 6-7. https://doi.org/10.35841/Biochemistry-Biotechnology.1000104

Mok, K. H., Xiong, W., \& Rahman, H. N. B. A. (2021). COVID-19 pandemic's disruption on university teaching and learning and competence cultivation: Student evaluation of online learning experiences in Hong Kong. International Journal of Chinese Education, 10(1), 221258682110070. https://doi.org/10.1177/2 2125868211007011

Qonita, R., A'tourrohman, M., Ulwiyah, U., \& Wijayanti, E. (2021). Student learning difficulties in online biochemistry practicum: An experiences during COVID-19. Bioeduscience, 5(1), 74-79. https://doi.org/ 10.22236/j.bes/515597

Queloz, A. C., Klymkowsky, M. W., Stern, E., Hafen, E., \& Kohler, K. (2017). Diagnostic of students misconceptions using the Biological Concepts Instrument ( $\mathrm{BCl}$ ): A method for conducting an educational needs assessment. Plos One, 12(5), 1-18. https://doi.org/10.1371/journal.pone.0176906

Raharjo, D., Ramli, M., \& Rinanto, Y. (2019). Diagnostic test assessment on protist misconception. JPBI (Jurnal Pendidikan Biologi Indonesia), 5(2), 335-344. https://doi.org/10.22219/jpbi.v5i2.7685

Rajhans, V., Memon, U., Patil, V., \& Goyal, A. (2020). Impact of COVID-19 on academic activities and way forward in Indian optometry. Journal of Optometry, 13(4), 216-226. https://doi.org/10.1016/ j.optom.2020.06.002

Sesli, E., \& Kara, Y. (2012). Development and application of a two-tier multiple-choice diagnostic test for high school students' understanding of cell division and reproduction. Journal of Biological Education, 46(4), 214-225. https://doi.org/10.1080/00219266.2012.688849

Singhal, T. (2020). A review of Coronavirus Disease-2019 (COVID-19). The Indian Journal of Pediatrics, 87(4), 281-286. https://doi.org/10.1007/s12098-020-03263-6

Susanti, R. (2018). Misconception of biology education student of teacher training and education of Sriwijaya University to the concept of photosynthesis and respiration. Journal of Physics: Conference Series, 1022, 012056. https://doi.org/10.1088/1742-6596/1022/1/012056

Suwono, H., Prasetyo, T. I., Lestari, U., Lukiati, B., Fachrunnisa, R., Kusairi, S., Saefi, M., Fauzi, A., \& Atho'lllah, M. F. (2021). Cell Biology Diagnostic Test (CBD-Test) portrays pre-service teacher misconceptions about biology cell. Journal of Biological Education, 55(1), 82-105. https://doi.org/ 10.1080/00219266.2019.1643765

Thibaut, D., \& Schroeder, K. T. (2020). A case-based learning approach to online biochemistry labs during COVID-19. Biochemistry and Molecular Biology Education, 48(5), 484-485. https://doi.org/10. 1002/bmb.21408

Tompo, B., Ahmad, A., \& Muris, M. (2016). The development of discovery-inquiry learning model to reduce the science misconceptions of junior high school students. International Journal of Environmental and Science Education, 11(12), 5676-5686. http://www.ijese.net/makale_indir/732

Üce, M., \& Ceyhan, I. (2019). Misconception in chemistry education and practices to eliminate them: Literature analysis. Journal of Education and Training Studies, 7(3), 202-208. https://doi.org/ 10.11114/jets.v7i3.3990

Usman, M. (2018). Biochemistry and Molecular Biology is the major tool for the development of health and basic need of daily life, in the developing countries in the world. EuroScicon Congress on Biochemistry, Molecular Biology \& Allergy, 4. https://doi.org/10.21767/2471-8084-C4-018

Wu, Y. C., Chen, C. S., \& Chan, Y. J. (2020). The outbreak of COVID-19: An overview. Journal of the Chinese Medical Association, 83(3), 217-220. https://doi.org/10.1097/JCMA.0000000000000270 
Yates, T. B., \& Marek, E. (2014). Teachers teaching misconceptions: a study of factors contributing to high school biology students' acquisition of biological evolution-related misconceptions. Evolution: Education and Outreach, 7, 7. https://doi.org/10.1186/s12052-014-0007-2

Yusuf, B. N. (2020). Are we prepared enough? A case study of challenges in online learning in a private higher learning institution during the COVID-19 outbreaks. Advances in Social Sciences Research Journal, 7(5), 205-212. https://doi.org/10.14738/assrj.75.8211 